Available online at GSC Online Press Directory

GSC Biological and Pharmaceutical Sciences

e-ISSN: 2581-3250, CODEN (USA): GBPSC2

Journal homepage: https://www.gsconlinepress.com/journals/gscbps

(SHORT COMMUNICATION)

\title{
Free radical scavenging activity of two edible vegetables from the Niger delta region of Nigeria
}

\author{
Baba Haruna ${ }^{1,2,{ }^{*}}$, Vwioko Oghoifor ${ }^{1}$ and Timikare Jeffrey ${ }^{1}$ \\ ${ }^{1}$ Department of Pharmaceutical and Medicinal Chemistry, Faculty of Pharmacy, Niger Delta University, Wilberforce \\ Island, Bayelsa state, Nigeria. \\ ${ }^{2}$ Department of Pharmaceutical chemistry, Faculty of Pharmacy, Madonna University, Elele, Nigeria.
}

Publication history: Received on 23 August 2018; revised on 26 September 2018; accepted on 27 October 2018

Article DOI: https://doi.org/10.30574/gscbps.2018.5.2.0092

\begin{abstract}
Oxidative stress and diseases that have their aetiology and pathophysiology in reactive oxygen species can be prevented by medicinal plants and herbs. We undertook in this study, to investigate the free radical scavenging activity of dichloromethane (DCM) and ethanol (ETOH) extracts of Lasianthera africana and Gongronema latifolium in vitro using 2, 2, diphenyl-1-picrylhydrazine (DPPH). The leaves of both plants were obtained locally, washed, dried and pulverized using mechanical grinder. The powdered materials were defatted using n-hexane and subsequently extracted with DCM and thereafter with ETOH. The DPPH scavenging potentials of the extracts were then evaluated. The percentage inhibition of the DCM and ETOH extracts were; 46.2 and $80 \%$ respectively for L. africana and 37.2 and 82.6 respectively for $G$. latifolium. The standard substance (quercetin) produced 98.4 per cent inhibition at $1 \mathrm{mg} / \mathrm{mL}$. The IC 50 for the $L$. africana were; 2.017 and $3.256 \mathrm{mg} / \mathrm{mL}$; DCM and ETOH extracts respectively. While that of G. latifolium were 1.495 and $1.116 \mathrm{mg} / \mathrm{mL}$ respectively for DCM and ETOH extracts. The standard substance produced IC 50 of $0.55 \mathrm{mg} / \mathrm{mL}$. The DPPH inhibitory activity was found to be prominent with the ETOH extracts of both plants. The result from this study validates the use of the leaves of both plants as supplements to improve health conditions and quality of life in general.
\end{abstract}

Keywords: Gongronema latifolium; Lasianthera africana; Free radical; Phytochemical

\section{Introduction}

Reactive oxygen species are responsible for oxidative stress and so many other degenerative diseases such as diabetes, inflammatory and cardiovascular disorders. Medicinal plants and herbs are veritable sources of natural antioxidants that can be used in the chemoprevention of such disorders [1]. Plant secondary metabolites such as flavonoids are responsible for the properties possessed by medicinal plants. Some organic and inorganic compounds such as coumarins, phenolic acids and antioxidants micronutrients; $\mathrm{Cu}, \mathrm{Mg}, \mathrm{Zn}$ also contribute to the efficacy of most medicinal plants [1]. The Niger delta is home to some important herbs in Nigeria that are consumed by the natives either for nutritive or therapeutic purposes. Lasianthera africana and Gongronema latifolium are two of such vegetable herbs.

L. africana, (BEAUV), family; Icacinaceae, is one of the top six commonly consumed green leafy vegetables by Efik and Ibibio ethnic groups of Nigeria [2]. It is locally called "editan" by Efiks and Ibibios. It is a perennial, glabrous, shrub that reaches a height of $61-136 \mathrm{~cm}$ [3]. Four local varieties characterized by their taste, leaf colour and ecological distribution are known among the Ibibios [4]. The varieties are "afia" (white variety) "obubit" (black variety), "idim" (riverine variety) and "Akai" (forest variety). The use of $L$. africana predates modern history. It is used in the preparation of soups and as decoctions, for the treatment of various diseases [5]. The leaf of L. africana is reported to be rich in phytochemicals of nutritional and medicinal importance [6]. Preliminary screening of the leaves showed the

\footnotetext{
${ }^{*}$ Corresponding author

E-mail address: babharun1@gmail.com
}

Copyright (C) 2018 Author(s) retain the copyright of this article. This article is published under the terms of the Creative Commons Attribution Liscense 4.0. 
presence of some secondary metabolites such as flavonoids, alkaloids, anthraquinones, saponins and tannins in all the four ethno varieties [4]. The leaf of L. africana is commonly used for nutritional purpose and medicinally in the treatment of fever, malaria and inflammatory diseases.

G. latifolium (Benth Hook), belongs to the family Asclepiadaceae and is a tropical rainforest plant primarily used as spice and vegetable in food [7]. Gongronema is a large genus that includes several major cultivated species including Gongronema latifolium, Gongronema bracteolatum, Gongronema obscurum, Gongronema curtisii, Gongronema wrayi, Gongronema angolense. G. latifolium is listed among the twenty-eight medicinally important vegetables of south west Nigeria [8] and also one of the aromatic plants of medicinal importance from Nigeria [9]. G. latifolium is known as "utazi" and "arokeke" in the Eastern and Western Nigeria respectively. It is an important medicinal plant, spice and vegetable. Some pharmacological test conducted in the past have indicated promising hypoglycaemic activities and also interesting antibacterial, anti-inflammatory, hepatoprotective, antiplasmodial, anti-asthmatic, anti-ulcer, analgesic, antipyretic and antisickling activity [10]. Preliminary phytochemical screening of G. latifolium leaves revealed the presence of alkaloids, saponin, tannins, flavonoids and glycosides, [11].

\section{Material and methods}

\subsection{Chemicals}

All solvents used in the experiment (n-hexane, dichloromethane, ethyl acetate, absolute ethanol, methanol) were purchased from Loba Chemic Pvt. Ltd (India). Quercetin, 2, 2-diphenyl-1-picrylhydrazine (DPPH), gallic acid, Folin ciocalteu's reagent and sodium carbonate were purchased from sigma chemicals (USA). All other chemicals and reagents used were of analytical grade.

\subsection{Plant materials}

The leaves of Lasianthera Africana and Gongronema latifolium were purchased from Agudama market, Yenagoa town, Bayelsa State (South of Nigeria). They were identified and authenticated by Dr. T. Oladele, Department of Pharmacognosy and herbal medicine, Faculty of Pharmacy, Niger Delta University. The leaves were oven dried at $40{ }^{\circ} \mathrm{C}$ and pulverized into fine powder using a mechanical grinder.

\subsection{Extraction}

The powdered materials ( $400 \mathrm{~g}$ ) were extracted by macerating with $\mathrm{n}$-hexane followed by dichloromethane and then absolute ethanol respectively with occasional shaking and allowed to stand, followed by filtration at room temperature. Each extraction was done three times to ensure complete extraction. The filtrate from each respective extract of $\mathrm{n}$ Hexane, dichloromethane and absolute ethanol were concentrated by evaporating on the water bath set at $35{ }^{\circ} \mathrm{C}$.

\subsection{Free radical scavenging activity}

The electron donating ability of the extracts was measured by bleaching of the purple coloured solution of 2, 2-diphenyl1-picryl-hydrazyl radical (DPPH) according to the method of Ebrahimzadeh et al [13, 14, 15] with a slight modification, a $0.5 \mathrm{mM}$ DPPH solution in methanol was prepared and then, $1 \mathrm{~mL}$ of this solution was mixed with $3 \mathrm{~mL}$ of the extract solution, concentrations $(0.2-1 \mathrm{mg} / \mathrm{mL})$. The mixture was shaken and left to stand in a dark cupboard at room temperature for $30 \mathrm{~min}$ and the absorbance of the resulting solution was measured at $517 \mathrm{~nm}$. The percentage (\%) DPPH radical scavenging was calculated using the following formula;

$$
\% \text { DPPH scavenging activity }=\frac{\mathrm{A}_{0}-\mathrm{A}_{1}}{\mathrm{~A}_{0}} \times 100
$$

Where $A_{0}$ and $A_{1}$ are the absorbance of the blank and sample respectively, after 30 min. The antiradical activity was carried out in triplicate per treatment and the IC $_{50}$ (concentration required to cause a $50 \%$ DPPH inhibition) was estimated. Quercetin was used as the positive control.

\subsection{Statistical analysis}

Statistical analysis was performed with graph pad prism 7 demo. Differences were tested for significance by linear regression procedure, using a significance level of $\mathrm{P} \leq 0.05$. 


\section{Results and discussion}

Table 1 Percentage DPPH scavenging effect of dichloromethane and ethanol extracts of the leaf of $L$. africana and quercetin

\begin{tabular}{llll}
\hline $\begin{array}{l}\text { Concentration } \\
\text { (mg/mL) }\end{array}$ & \multicolumn{3}{c}{ Percentage of inhibition (\%) } \\
& DCM extract & ETOH extract & Quercetin \\
\hline 1 & 46.20 & 80.00 & 98.40 \\
0.8 & 42.10 & 79.70 & 98.30 \\
0.6 & 39.30 & 78.70 & 98.20 \\
0.4 & 37.90 & 77.90 & 97.30 \\
0.2 & 30.60 & 77.30 & 93.00 \\
\hline
\end{tabular}

Table 2 Percentage inhibition for dichloromethane and ethanolic extract of the leaves of G. latifolium and quercetin

\begin{tabular}{llll}
\hline $\begin{array}{l}\text { Concentration } \\
\text { (mg/mL) }\end{array}$ & \multicolumn{3}{c}{ Percentage of inhibition (\%) } \\
& DCM extract & ETOH extract & Quercetin \\
\hline 1 & 37.21 & 82.64 & 98.42 \\
0.8 & 30.94 & 80.94 & 98.31 \\
0.6 & 20.31 & 76.25 & 98.17 \\
0.4 & 18.94 & 77.96 & 97.17 \\
0.2 & 11.30 & 70.43 & 93.03 \\
\hline
\end{tabular}

\subsection{DPPH radical scavenging activity}

The free radical scavenging activity of the extracts of the leaf of L. africana and G. latifolium was determined using DPPH method, a stable free radical which is widely used to assess the radical scavenging activity of antioxidant compounds $[12,13,14]$. The antioxidant effect is proportional to the decolourization and disappearance of the purple colour of DPPH. The model of scavenging the stable DPPH radical is a widely used method to evaluate the free radical scavenging ability of various samples [15]. It was found (Table 1 and 2), that the increase in concentration of the extract of $L$. Africana, $G$. latifolium and the standard quercetin favours the radical scavenging activity. This means that, the higher the concentration, the more the free radical scavenging activity. High absorbance is an indication of high concentration of formed peroxides-Therefore low concentration indicates high antioxidant activity [16]. The high phenolic and flavonoid contents of the leaf of L. africana and G. latifolium are responsible for high antioxidant activity of the leaf. Phenols and polyphenols compounds such as flavonoids found in food products derived from plant sources such as Lasianthera africana and G. latifolium have shown to possess significant antioxidant activities [17].

From linear regression analysis, the (DCM) and (ETOH) extracts of L. africana indicated; $\mathrm{y}=3.6 \mathrm{x}+76.56, \mathrm{r}^{2}=0.9803$ and $\mathrm{Y}=17.7 \mathrm{x}+28.6, \mathrm{r}^{2}=0.9417$ respectively. That of $G$. latifolium is; $\mathrm{y}=31.91 \mathrm{x}+4.594, \mathrm{r}^{2}=0.96$ and $\mathrm{y}=13.7 \mathrm{x}+69.42$, $r^{2}=0.83$ for DCM and ETOH respectively. While quercetin indicated; $y=5.9 x+93.5, r^{2}=0.6577$. The IC 50 (concentration required to cause a 50\% DPPH inhibition) for the leaf extracts of $L$. africana was obtained from linear regression curve as 2.017 and $3.256 \mathrm{mg} / \mathrm{mL}$; DCM and ETOH extracts respectively. While that of G. latifolium, were 1.495 and 1.116 $\mathrm{mg} / \mathrm{mL}$ respectively. The standard substance; quercetin produced $0.55 \mathrm{mg} / \mathrm{mL}$ as its $\mathrm{IC}_{50}$. Low IC50 indicates greater antioxidant activity [18]. This means that the standard substance; quercetin has more potential antioxidant activity than the leaf extracts. It is shown that only flavonoids with certain structure and particularly hydroxyl group in certain positions in their molecule can act as proton donating and show radical scavenging activity. Similarly, the extracts contain complex mixtures of many different compounds with distinct activities $[19,20]$. The antioxidant activities of putative antioxidants have been attributed to various mechanisms; among these are prevention of chain initiation, binding of transition ion catalysts, decomposition of peroxides, prevention of continued hydrogen abstraction and radical scavenging $[21,22]$. In addition, it has been reported that the free-OH groups in phenolic compounds are mainly 
responsible for antioxidant activity [23]. Thus, these results may suggest that DPPH scavenging activity is an indication of potential antioxidant activity for the leaf extracts of L. africana and G. latifolium.

\section{Conclusion}

In this study, the free radical scavenging and antioxidant activity was found to be more in the ETOH extracts compared to the DCM extracts. This shows that the antiradical agents are predominantly in the polar extract; which in no doubt should be the case because the polar phase should contain more of the phenolic compounds that may be responsible for the radical scavenging activity. The findings from this study has provided a rationale for the ethnobotanical use of the plants to improve health conditions; further work should be carried out to isolate chemical constituents responsible for their activity.

\section{Compliance with ethical standards}

\section{Acknowledgments}

This work was fully funded by the Niger Delta University based TET fund research grant awarded to Dr. Haruna Baba and this is hereby acknowledged.

\section{Disclosure of conflict of interest}

The authors declare no conflict of interest in this work.

\section{References}

[1] Hurrell R. (2003). Influence of vegetable protein sources on trace element and mineral availability. Journal of Nutrition, 133(9), 29733-29775.

[2] Williams IO, Parker RS and Swanson J. (2009). Vitamin A content of South Eastern Nigerian vegetable dishes, their consumption pattern and contribution to vitamin A requirement. Pakistan Journal of Nutrition, 8(7), 10001004.

[3] Hutchison J and Dalziel JM. (1973). Flora of West Tropical Africa (2 ${ }^{\text {nd }}$ ed.) Crown Agents, London, 638.

[4] Bassey ME, Etuk EUI, Ubom R and Obop IE. (2006). Chemotaxonomic study of Lasianthera africana (lcacinaceae) in Akwa Ibom State of Nigeria. Nigeria Journal of Botany, 19, 99-102.

[5] Sofowora, A. (1993). Screening plants for bioactive agents. Medicinal plants and traditional medicine in Africa, spectrum books Ltd, Ibadan, 134.

[6] Ebana RUB, Essien Al and Ekpa OD. (1995). Nutritional and potential medicinal values of the leaves of Lasianthera africana (BEAUV). Global journal of pure science, 1, 1-8.

[7] Nwosu MO and Malize N. (2006). An anatomic systematic study of medicinal plants of Nigeria latifolium (benth) (Asclepladaceae). Journal of Economic and Taxonomic Botany, 30(2), 5-10

Gongronema

[8] Ayodele AW. (2008). The medicinally important leafy vegetable of South Western Nigeria. http:llwww.siu/ebl/leaflets/ayodele.com.

[9] Ogunwande IA, walker TM, and Setzer WN. (2007). A review of aromatic herbal plants of Medicinal importance from Nigeria. Natural product communication, 2(12), 1311-1316.

[10] Morebise O, Fafunso MA, Makinde JM, Olajide OA and Awe CO. (2002). Antiinflammatory property of the leaves of Gongronema latifolium. Phytotherapy Research, 16, 57-67.

[11] Nwanjo HU, Okator MC, Oze GO. (2006). Antilipid peroxidative activity of Gongronema latifolium in streptozotocin induced diabetes rats. Nigeria Journal of Physiological Science, 221 (2), 61-65

[12] Ebrahimzadeh MA, Hosseinimehr SJ, Hamidinia A and Jafari M. (2008a). Antioxidant and free radical scavenging activity of Feijoa sallowiana fruits peel and leaves. Pharmacologyonline 1, 7-9.

[13] Ebrahimzadeh MA, Pourmorad F and Bekhradnia AR. (2008b). Iron chelating activity screening, phenol and flavonoid content of some medicinal plants from Iran. Africa Journal of Biotechnology, 32, 43-49. 
[14] Ebrahimzadeh MA, Pourmorad, F and Hafezi, S. (2008c). Antioxidant Activities of Iranian Corn Silk. Turkish Journal of Biology, 32, 43-49.

[15] Lee SE, Hwany HJ, Ha JS, Jeong HS and Kin JH. (2003). Screening of medicinal plant extracts for antioxidant activity. Life science, 73,167-169.

[16] Yen GH and Chen HY. (1995). antioxidant activity of various tea extracts in relation to their antimutagenicity. Journal of Agricultural and food chemistry, 43, 27-32.

[17] Van Acker SA, Berg DJ, Tromp MN, Griffioen DH, Van Bennekom WP, van der Vijgh WJ and Bast A. (1996). Structural aspects of antioxidant activity of flavonoids. Free Radical Biology and Medicine, 20(3), 331-342.

[18] Abdelwahab SI, Abdul AB, Elhassan MM, Mohan S Alzubairi AS and Mariod AA (2009a). Antimicrobial and free radical scavenging activities of dichloromethane extract of Goniothalamus umbrosus. International Journal of Tropical Medicine, 4, 32-36.

[19] Mensor LL, Menezes FS, Leitao GG, Reis AS, Dos santos TC, Coube CS and Leitao SG. (2001). Screening of Brazilian plant extracts for antioxidant activity by the use of DPPH free radical method. Phytotherapy Research, 15, 127130.

[20] Hou WC, Lin RD, Cheng KT, Hung YT, Cho CH, Chen CH, Hwang SY and Lee MH. (2003). Free radical-scavenging activity of Taiwanese native plants. Phytomedicine, 10, 170-175.

[21] Diplock AT. (1997). Will the good fairies please prove us that vitamin E lessens human degenerative diseases? Free radical research. 27, 511-532.

[22] Heinonen IM, Lehtonen PJ and Hopia A. (1998). Antioxidant Activity of Berry and Fruit Wines and Liquors. Journal of Agricultural and Food Chemistry, 46, 25-31.

[23] Wengs XC and Wang W. (2000). Antioxidant activity of various tea extracts in relation to their antimutagenicity. Journal of Agricultural and Food Chemistry, 43, 27-32.

\section{How to cite this article}

Baba H, Vwioko $\mathrm{O}$ and Timikare J. (2018). Free radical scavenging activity of two edible vegetables from the Niger delta region of Nigeria. GSC Biological and Pharmaceutical Sciences, 5(2), 69-73. 